\title{
RURAL COMMUNE'S WEBSITE CONTENTS IN THE PROCESS OF FORMING ITS TOURIST IMAGE. THE CASE OF CZOSNÓW, POLAND
}

\author{
JOLANTA ĆWIKLIŃSKA
}

\begin{tabular}{|c|c|}
\hline & $\begin{array}{l}\text { Warsaw School of Economics } \\
\text { e-mail: jolanta.cwiklinska@sgh.waw.pl }\end{array}$ \\
\hline $\begin{array}{l}\text { RECEIVED } \\
\text { ACCEPTED }\end{array}$ & $\begin{array}{l}18 \text { March } 2015 \\
10 \text { August } 2015\end{array}$ \\
\hline $\begin{array}{l}\text { JEL } \\
\text { CLASSIFICATION }\end{array}$ & D83, L83, M31 \\
\hline KEYWORDS & content analysis, destination image, image hallmarks, information search, website contents \\
\hline ABSTRACT & $\begin{array}{l}\text { The process of tourism experiences is usually initiated by images of a particular region formed by people before } \\
\text { the intended journey. Searching for information about this region is often the second stage in this process. Now- } \\
\text { adays, the contents available in the Internet play a very important role both at the stage of forming the images } \\
\text { and at the stage of searching for information. Growing popularity of social media enables people to interact } \\
\text { with each other, thus tourists may not only have access to objective facts but also to subjective opinions on the } \\
\text { region itself and on what is going on there. There is however, still a segment of tourist product consumers, who } \\
\text { will search for information about a particular region on its official websites rather than in social media. It results } \\
\text { not only from limited abilities of older generation consumers to function in social media, but also from the nature } \\
\text { of tourist visit in the region. For a big city inhabitant, who takes a spontaneous decision to spend a weekend in } \\
\text { a nearby commune offering recreation or cultural attractions, it is easier to get the required information about } \\
\text { tourist attractions, accommodation etc. on a well-structured official website of the commune than to follow } \\
\text { a vast number of posts and comments in social media. Information that is easily accessible, regularly updated } \\
\text { and most of all useful for the potential tourists will certainly affect the image of the commune that is formed in } \\
\text { the tourist's mind. } \\
\text { The overall objective of this research is to analyze the way in which the contents presented on the official } \\
\text { website of Czosnów commune are correlated with tourism image hallmarks of the commune. Therefore, the } \\
\text { first initial part of the research deals with the identification of strong image hallmarks serving as a basis for } \\
\text { image formation before the intended visit. The core part of the research focuses on analyzing the official } \\
\text { website contents in terms of the identified image hallmarks' presence and contexts in which they are presented. } \\
\text { The practical objective of the research is to analyze the contents' usefulness for the potential tourists forming } \\
\text { their image of the commune or searching for information before the intended visit. }\end{array}$ \\
\hline
\end{tabular}




\section{Introduction}

The concept of image is constantly modified and redefined, primarily because it is used in a number of contexts by different disciplines (e.g. psychology, marketing, but also arts, geography, environmental planning). In tourism research the concept is often used in the context of destination image and is analyzed in two perspectives: in terms of understanding the behavior of tourists, who develop a certain mental construct based on some impressions, and in terms of designing effective tourism marketing strategies by destination stakeholders (Echtner, Ritchie, 2003: 38). In order to build effective positioning strategy for a particular destination, marketers and other destination stakeholders take efforts aimed at differentiating it from its competition in the minds of the consumers (Beerli, Martin, 2004). The process of building such strategy starts with identifying some superior resources or unique characteristics which may function as hallmarks of a destination image. Govers (2005: 35) specifies that "superior resources, which might be difficult for competing destinations to imitate, are generally to be found in both its unique natural environment (climate, wildlife or landscape) and its cultural heritage: a destination' s physical assets, sites reflecting its roots in terms of a rich history, religion, or other cultural expressions such as the arts, architecture and design". The identification of strong and attractive image hallmarks enables the stakeholders to build a marketing strategy projecting a positive destination image, which will affect tourists' evaluation of the destination and may have the potential of increasing the level of visitation.

The concept of image analyzed in terms of tourists' behavior is defined as "a set of complex mental impressions and total feeling that potential tourists hold of a product, place or tourism destination" (Matos et al., 2012: 109). The image forming process is affected by two groups of factors: types of information sources used in the process and personal factors (Beerli, Martin, 2004) of psychological and sociological nature. The psychological factors refer to consumer's rationality and emotionality. They include beliefs and attitudes, personality traits and perceptual and cognitive powers of prospective tourists which affect their process of evaluating the attractions of a destination and attributes of its image, thus motivate them to visit the destination (Lopes, 2011). Moreover, the cognitive component of the destination image has an impact on the affective component (Lin et al., 2007; San Martin, Rodriguez, 2008). The sociological factors include age, race, lifestyle, education level, previous visit to a destination (Tasci, 2007), country of origin (Bonn et al., 2005), or geographical distance from the destination (Gartner, 1993). Affected by a combination of personal factors, prospective tourists actively choose or are passively under the influence of different types of information sources: reference groups, commercial sources, media etc.

The concept of destination image needs some deconstruction nowadays, because as a result of online revolution tourists are faced with the proliferation of destination identities (Govers, Go, 2003: 13), with a growing number of information sources projecting different image attributes. The emphasis is thus on the first group of factors influencing the process of forming a destination image, that is on all different types of information sources. In the process of tourism experiences, searching for information about destination is one of the first steps (Gursoy, Umbreit, 2004), because before actually taking the trip, leisure travelers search for information, both in the pre- and the post-decision stages (Björk, Kauppinen-Räisänen, 2015). Information search behavior in consumer behavior studies is defined as an "activity to search for information stored in memory or acquisition of decision-relevant information from the environment" (Engel et al., 1995: 41). Some typical patterns of information search behavior for different segments of tourist product consumers can be distinguished by means of analyzing such factors as type of trip, degree of packaging, choice of destination, and choice of accommodation affecting the patterns (Biegger, Laesser, 2004). Generally, however, two types of information search that consumers undertake can be distinguished: 
internal and external search. Internal search is based on long-term memory of the consumer, while external search "involves independent sources, personal sources, marketer-based information and product experience" (Hawkins et al., 2010: 592).

Nowadays, the contents available in the Internet constitute a valuable source for external search. Indeed, "travellers have adopted the Internet as one of their primary sources for travel information" (Pan, Fesenmaier, 2006: 30 ), and destination marketing organizations consider the Internet to be their primary means of communicating with prospective tourists (Morrison et al., 2004; Hwang et al., 2006). Growing popularity of social media enables people to interact with each other, thus tourists may not only have access to objective facts but also to subjective opinions on the destination itself and on what is going on there. There is however, still a segment of tourist product consumers, who will search for information about a particular destination on its official website rather than in social media. It results not only from limited abilities of older generation consumers to function in social media, but also from the nature of tourist visit to a destination. For a big city inhabitant, who takes a spontaneous decision to spend a weekend in a nearby commune offering recreation or cultural attractions, it is easier to get the required information about tourist attractions, accommodation etc. on a well-structured official website of the commune than to follow a vast number of posts and comments in social media. Information that is easily accessible, regularly updated and most of all useful for the potential tourists will certainly affect the image of the commune that is formed in the tourist's mind.

Information search process that prospective tourists go through when they use the Internet is composed basically of three stages: (a) search, (b) primacy and (c) elaboration (see Figure 1). The nature of the first stage relies on the relationships between mental models of the destination that the prospective tourists have (e.g. images of the destination, prior knowledge and experience with travelling) and the search terms (words, phrases) they will use in search engines to identify possible websites (Kim, Fesenmaier, 2008: 3-4). The second stage focuses on choosing a particular website, which means in fact evaluating the relevance of the search engine results (Kim, Fesenmaier, 2008: 4). It is at this stage that prospective tourists formulate their first impression of the website. The third stage is the decision whether or not to navigate within the website, which obviously is affected by the first impression. At this stage prospective tourists will learn about the chosen website and about the destination.

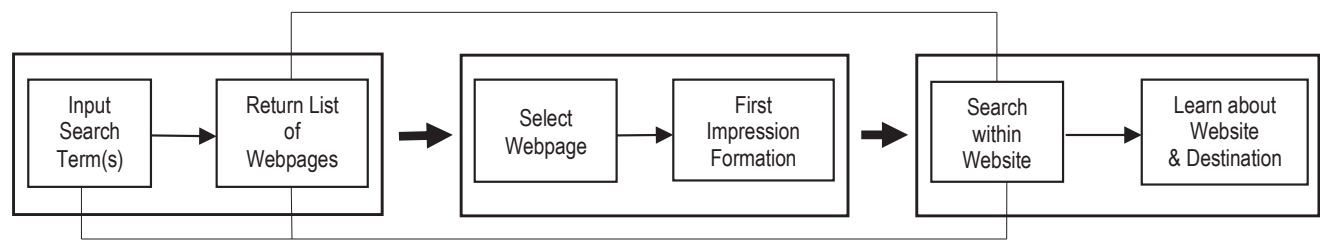

Figure 1. The process of information search using the Internet for travel planning

Source: Kim, Fisenmeier (2008): 4.

This research focuses on the third stage of the process of information search, when prospective tourists have already chosen an official website of a destination - rural commune of Czosnów - and want to get useful information about the destination, simultaneously forming their image of the place or crystallizing it, if they already have formed a primary image. The overall objective of this research is to analyze the way in which the contents presented on 
the official website of Czosnów commune are correlated with tourism image hallmarks of the commune. Therefore, the initial part of the research deals with the identification of strong image hallmarks serving as a basis for image formation process before the intended visit. As a result of field research (visiting local tourist attractions, talking with the inhabitants of the commune) held in the period from May to October 2014 and secondary materials analysis (tourist guides, articles in local media, advertising materials of tourist companies operating in the commune, documents of local authorities, institutions and associations) four strong image hallmarks of Czosnów commune have been identified.

The core part of the research focuses on analyzing the official website contents in terms of the four identified image hallmarks' presence and contexts in which they are presented. The practical objective of the research is to analyze the contents' usefulness for potential tourists forming/crystallizing their image of the commune or searching for information before the intended visit.

The technique applied in this research is content analysis used as a subjective interpretation of text content data through the systematic process of identifying and classifying themes and patterns (Hsieh, Shannon, 2005: 1278). However, limiting the research to text contents only would not be useful for the purposes of this research. A slightly wider definition of content analysis shows it a as "a research technique for making replicable and valid inferences from texts (or other meaningful matter) to the context of their use" (Krippendorf, 2005: 18). The fact that the above definition includes "other meaningful matter" widens the scope of analysis beyond texts to pictures, maps and symbols as well. It also emphasizes the context as an important element of the analysis. In case of this research the essential unit of analysis is a post (in the form of text, picture or film) on the official website of the commune. The choice of research technique is motivated by a belief that analyzing destination image through the content analysis of online publications can provide destination stakeholders with insights into the way they project online image to enhance the experiential nature of tourism (Govers, Go, 2005: 74).

In this research both quantitative and qualitative content analyses have been applied. Quantitative content analysis is used in mass communication studies, first of all, in order to objectively present quantitative description of explicit content in the process of communication, omitting implicit syntactic and semantic aspects embedded in the text (Weber, 1990) and all the aspects connected with the actual context. In case of this research quantitative content analysis might be limited to counting how many times a word or a picture denoting any of the identified image hallmark of Czosnów commune appears on its official website. Therefore, quantitative content analysis functions in this research merely as an introduction to qualitative content analysis.

The emphasis is put on "qualitative data reduction and sense-making effort that takes a volume of qualitative material and attempts to identify core consistencies and meanings" (Patton, 2002: 453). Qualitative content analysis may show aspects that are omitted in quantitative content analysis. Firstly, it may account for social context of the post. For example, by analyzing the authorship of the posts and not only how many and what key words are used in them, it is possible to draw some conclusions about the participation level of particular social actors of the commune (e.g. local authorities, cultural or educational institutions, business organizations, inhabitants) in the process of preparing tourist offer or building the image of the commune. Secondly, qualitative content analysis may reveal the physical context of a post, by for example examining when it was submitted. If a post referring to an attractive event in the commune appears as a coverage only after the event, then it has some power for building tourist image of the commune, but certainly does not have any potential as a tourist product offer. If however a post is submitted as 
an invitation early enough before the event, then it may have both the power for building tourist image and potential as a tourist product offer.

The scope of the research was limited to the official website of Czosnów commune, with no out-bound links taken into consideration. Thus, in the core part of the research the websites of the commune library and associations functioning in the commune have not been analyzed, although in the initial part of the research they have been a source of data used in the identification of the image hallmarks.

\section{Tourist image hallmarks of Czosnów commune}

Czosnów commune, located in the central part of Mazovian province, 16 kilometers north of Warsaw, is a rural commune of agricultural character. About $30 \%$ of its territory is covered by Kampinos National Park. Recreational activities in the commune include walking, biking and horse-riding (Czosnów Commune g, n.d.). Unique natural environment and short distance from metropolitan area of Warsaw make a combination of strong tourism potential, particularly weekend tourism in the period of spring, summer and early autumn.

The commune can also develop cultural tourism, because there is an ecumenical cemetery in Palmiry a mausoleum of the Nazi regime victims in the years 1939-1941 and The Palmiry Museum Place of Memory. The new building of the museum constructed in accordance with the pine-birch forest that surrounds a cemetery is characterized by glass and steel partitions and covered with a green roof (Inexhibit, n.d.). In the village of Wiersze there is another WW2 cemetery of 54 Home Army soldiers of the Kampinos Regiment killed in the battles with Germans in 1944 (All-Polish Computer Base of Military Cemeteries, n.d.). In 2004 a monument was raised in Wiersze to commemorate The Independent Republic of Kampinos, that is soldiers and inhabitants of this area who fought against German troops during the Warsaw Uprising in 1944 (Gołębiewski, n.d.). Another tourist image hallmark of the commune is Modlin and Kazuń Defendants Monument, located in Kazuń Nowy and commemorating the defendants of the Modlin Fortress in September 1939. The monument was constructed in 1957, but has a form typical for pre-WW2 period with Polish Legions eagle on top, that is why initially there were problems with installing the monument (Żagiel, 2002)

Summing up, Czosnów commune has at least four strong hallmarks of its tourist image: (1) cemetery and museum in Palmiry, (2) cemetery and monument in Wiersze, (3) Modlin and Kazuń Defendants Monument, and (4) Kampinos National Park. All of these hallmarks can serve as the basis for cultural tourism offer, but of course in case of the fourth hallmark this offer can be supported with recreational and sport elements.

\section{Tourism image hallmarks' presence and contexts on the commune's official website}

The homepage of Czosnów commune' official website (Czosnów Commune d, n.d.) is divided into 12 sections. In the first one entitled "Commune", an internet-user potentially interested in visiting this area will, first of all, find information about the history of the commune. The first post in this section presents a brief historical overview, mentioning the fact that Kazun is one the oldest places in the commune, while the villages of Wiersze, Brzozówka and Krogulec located in the Kampinos Forest are historically the newest ones, as "before the year 1743 the forest areas had not been inhabited" (Czosnów Commune e, n.d.). In the analyzed post, this is the only context in which the names of places connected with the image hallmarks appeared. Surprisingly, the historical overview does not include any reference to the defense of Kazuń and Modlin in 1939, nor to tragic events in Palmiry in the years 1939-1941 or in Wiersze in 1944. 
The next two posts in this section include information about commune's emblem (with no references to any of the image hallmarks) and information about commune's flag. The official post about the flag (dated 11 April 2006) presents 5 graphic projects chosen by a Contest Committee among 42 projects submitted. The post invites readers to vote on a chosen project, and later informs about the voting results. There is no information about the symbolic meaning of the projects, which in fact was of interest for the readers. There are six comments to this post, one of them includes a question: "what is the symbolic meaning of these colors and how do they refer to our commune", the next comment includes a reference to the strongest image hallmark: "maybe the green color means the surrounding of the Kampinos National Park?" (Czosnów Commune b, n.d.). This question is not answered and in fact this is the only reference to image hallmark in this part of section "Commune", coming, however, from the internet-users not from the website administrator.

In the subsequent part of this section there is a post presenting local authorities (photographs, names, telephone numbers), a post with the map of the commune and a post describing the commune's location. The latter one includes one sentence referring directly to two of the identified image hallmarks: "It covers the area between The Vistula river and Kampinos Forest (the most well-known place in the Forest is cemetery in Palmiry, where celebrations commemorating those killed in the WW2 are held annually)" (Czosnów Commune f, n.d.). All together, section 1 "Commune" does not contain too many references to image hallmarks, therefore its potential as an instrument of building tourist image of the commune is quite limited.

The next 6 sections of the website (2. Institutions, 3. Education, 4. Waste Management, 5. Taxes and Local Fees, 6 . Organizations, 7. Public Transport) do not include any references to the identified image hallmarks, because they deal mainly with practical information that is useful, first of all, for the inhabitants of the commune not for the prospective tourists searching for information before the intended visit. Only the content of the seventh section on public transport (e.g. bus lines timetables) may be useful for tourists. It is worth noting, however, that even if the information contained in these sections is not directly useful, it may indirectly affect the process of image formation: those tourists who are interested in ecological issues may be willing to consult the Waste Management section, those interested in cultural offer may be willing to consult the Institutions section or Organizations section.

The eighth section entitled "Gallery" (Czosnów Commune c, n.d.) includes albums of photographs documenting events of special importance for the commune. The albums show cultural events held in the commune (e.g. "Czosnów Days", "Classic Music Concert"), sport events (e.g. "Czosnów Commune Head Cup 5th Indoor Tournament") or projects and investments in the commune (e.g. "The Construction of Kindergarten in Kazuń"). The total number of photographs in the "Gallery" section is 1997 in 85 thematic albums. Each album is equipped with one- or twosentence description of the documented event and the date of taking the photograph. Unfortunately, the albums are not arranged chronologically on the four pages of this section, and only some of the albums include photographs with captions.

The quantitative analysis of the albums contents (nearly 2000 photographs) revealed 82 photographs showing the tourist image hallmarks identified in the initial part of this research. 45 photos show cemetery and/or monument in Wiersze, 31 photos refer to cemetery in Palmiry, 5 pictures refer to Kampinos National Park, and one photograph shows Modlin and Kazuń Defendants Monument (see Table 1). 
Table 1. Tourist image hallmarks of Czosnów commune in "Gallery" section of the commune's website

\begin{tabular}{|c|c|c|c|c|}
\hline \multirow[b]{2}{*}{ Title of the album } & \multicolumn{4}{|c|}{ Number of photographs showing and/or referring to: } \\
\hline & $\begin{array}{l}\text { Cemetery } \\
\text { and museum } \\
\text { in Palmiry }\end{array}$ & $\begin{array}{c}\text { Cemetery } \\
\text { and monument } \\
\text { in Wiersze }\end{array}$ & $\begin{array}{l}\text { Modlin and Kazuń } \\
\text { Defendants } \\
\text { Monument }\end{array}$ & $\begin{array}{c}\text { Kampinos } \\
\text { National } \\
\text { Park }\end{array}$ \\
\hline Patriotic/Religious Celebrations 14th November 2013 & & & 1 & \\
\hline Running Picnic 1st September 2013 & 4 & & & \\
\hline In Memory of Those Days 21st August 2013 & & 34 & & \\
\hline 6th Czosnów Days & & 1 & & \\
\hline Maciej Rataj - A Prayer Palmiry 2011 & 7 & & & 1 \\
\hline Czosnów Days 2010 Sunday & & 1 & & \\
\hline Photo Contest & 1 & & & \\
\hline Nature & & & & 2 \\
\hline Winter Landscapes & & 2 & & \\
\hline Italian delegation in Czosnów Commune June 2005 & 1 & & & 1 \\
\hline Maciej Rataj - Holy Mass Palmiry 25th June 2006 & 9 & & & \\
\hline Independent Kampinos Republic Monument 2006 & & 6 & & \\
\hline Holy Mass to Commemorate the Murdered in Palmiry & 4 & & & \\
\hline The Visit of Lithuanian Teachers 27-29th April 2007 & 1 & & & \\
\hline Celebrations in Palmiry 28th June 2007 & 4 & & & \\
\hline Barefoot in the dew & & 1 & & \\
\hline Czosnów days 6th September 2009 & & & & 1 \\
\hline Total & 31 & 45 & 1 & 5 \\
\hline
\end{tabular}

Source: own elaboration on the basis of Czosnów commune official website.

Detailed qualitative analysis of this content shows a great role of Home Army Soldiers Cemetery and Independent Kampinos Republic Monument in Wiersze in the process of building the commune's image. It is implied not only by the number of photographs, but also by the context in which the photos are taken. It is obvious that the basic context (thus also prevailing in numbers) for this hallmark are the celebrations commemorating the Home Army soldiers. The "Gallery" section includes two quite big albums documenting celebrations held in this place: one entitled "Independent Kampinos Republic Monument 2006", which is a photo coverage of religious celebration held on the cemetery on 20 August 2006 with several pictures clearly showing the monument, and one entitled "In Memory of Those Days", which is a photo coverage of patriotic celebration commemorating the 69th anniversary of Warsaw Uprising, held in Wiersze in August 2013 with pictures of both the monument and the cemetery.

Apart from this basic context, there were two other contexts for this hallmark, showing how important this place is for the inhabitants and local authorities of the commune. The Independent Kampinos Republic Monument is present in two albums entitled "Czosnów Days 2010" and "Czosnów Days 2012". The context here is a group photograph of people participating in a mass cycling event and stopping at the Monument to commemorate the historical past of the commune. This context shows the efforts taken by the local authorities to combine a mass event of sport/recreational nature with the elements of historical/educational value.

Moreover, in an album entitled "Barefoot in the dew", documenting a project of Polish and Lithuanian youth within the framework "The Youth in Action", together with pictures showing visits, workshops, meetings and happenings, there is one photograph presenting young people visiting the cemetery in Wiersze. The qualitative analysis of the 
described photographs' three contexts shows that the image hallmark of the cemetery and monument in Wiersze is deeply rooted in the social space of the commune. It is an important place not only for the official celebrations, but also functions as a kind of visiting card of the commune in its contacts with foreign visitors. Finally, the forth context for this hallmark is of purely visual, artistic nature, without any patriotic/religious or educational/historic references. In an album entitled "Winter landscapes" there are two artistic photographs of the cemetery covered with snow.

When researching the contexts of visual content referring to this hallmark, it is worth analyzing one more album in the "Gallery" section entitled "Pole and Hungarian cousins be". The album does not contain photos depicting this hallmark, but refers to elements that might complete tourist image of the commune. The description of the album says: "On 29th June 2014 a patriotic-religious celebration was held in Wiersze, with the participation of Polish and Hungarian Defense Ministers, representatives of Hungarian embassy" (Czosnów Commune h, n.d.). The photographs in the album show the celebration, unfortunately they do not have captions. Neither the cemetery nor the monument are shown on the pictures, so it implies that the event was held in another place in the village of Wiersze. One of the photographs is of particular interest, as it shows the act of unveiling memorial plagues commemorating Home Army soldiers. If the plaques are in the vicinity of the cemetery or the monument, than they might serve as another valuable element of this image hallmark. Therefore, the lack of any information about them on the commune's website is quite astonishing.

The quantitative and qualitative analysis of this part of "Gallery's" content which refers to the tourist image hallmark of cemetery and monument in Wiersze shows that tourists forming their image of the commune before the intended visit or searching for information about it have access to quite rich material about this image hallmark thanks to the official commune's website. They can see what the cemetery and the monument look like, they can learn what events have already been held there, they can form their own opinion about the role of this place in the life of the commune. However, tourists planning a visit to this place might consider visiting other places connected with the character of this hallmark, e.g. the memorial plagues. In this section of the website no information about such places is available. This shortcoming could be easily overcome by giving proper, informative captions to the photographs.

The quantitative analysis of "Gallery's" content shows that the next image hallmark (in terms of the number of photographs) is the cemetery in Palmiry. The qualitative analysis of the contexts in which the hallmark appears reveals that the basic context is (similarly to the previous hallmark's context) patriotic/religious celebration, but this time clearly focusing on commemorating Maciej Rataj - the Marshal of the Sejm, who was executed in Palmiry in 1940.

In an album entitled "Maciej Rataj - Holy Mass Palmiry 2006", among 16 photos, there are 9 pictures showing the tomb of M. Rataj or delegations laying wreaths at the tomb. Another album (also from 2006) entitled "Holy Mass to Commemorate the Murdered in Palmiry" shows 15 photos, with 4 of them referring to the image hallmark: two of them depict the tomb of M. Rataj, the third one shows veterans form Czosnów with the background view of the cemetery, and the fourth one entitled "The Crosses of Palmiry" is an artistic view of the cemetery. A similar context can be found in two later albums. The one form June 2007 entitled "Celebrations in Palmiry" contains altogether 9 photographs: one of them shows the tomb of M. Rataj and three others have a general view of the cemetery as a background. The second album, entitled "Maciej Rataj - A Prayer Palmiry 2011", includes three photos of the cemetery itself, and four photos with a cemetery as a background. 
The visual contents referring to the Palmiry cemetery as an image hallmark of Czosnów commune, particularly the contents showing the tomb of $\mathrm{M}$. Rataj are presented also in the context of foreign visits in the commune. An album entitled "Italian Delegation in Czosnów Commune June 2005" has one photo showing foreign visitors at the tomb, and an album "The Visit of Lithuanian Teachers 27-29 April 2007" has one photo depicting foreign visitors laying wreaths at the tomb.

A slightly different context can be found in 4 pictures in an album entitled "Running Picnic 1st September 2013". The photos present a group of people on the cemetery in Palmiry, laying wreaths at one the tombs. Unfortunately, the photos do not have captions, but on one of them it can be seen that it is the tomb of Janusz Kusociński, 1932 Summer Olympics winner, executed in Palmiry in 1940. It is the only reference to this person in the analyzed part of the "Gallery" section.

Moreover, similarly to the previous tourist image hallmark, there is a purely visual, artistic context for this hallmark as well: an album "Photo Contest" includes one photo entitled "November colors on the cemetery in Palmiry".

The quantitative and qualitative analysis of this part of "Gallery's" content which refers to the tourist image hallmark of cemetery and museum in Palmiry reveals that only the first of these elements (the cemetery) is present in the contents of this section. The contexts in which this element appears are symmetrical to the contexts of the previous image hallmark: most strongly represented is the context of patriotic/religious celebrations. Apart from this leading context, there is context of combining a mass event of sport/recreational nature (Running Picnic) with the elements of commemorating historical events. The third context is the one of foreign visitors in the commune paying a visit to the place, and finally the fourth most weakly represented is the artistic context.

The quantitative analysis of "Gallery's" content shows that the next image hallmark (in terms of the number of photographs) is Kampinos National Park. There are merely 5 photographs, 2 of which actually show a certain fragment of this image hallmark: these are artistic pictures of flora and fauna in Kampinos National Park placed in an album "Nature" from December 2005. The remaining 3 pictures in fact refer to the tourist image hallmark rather than show it. One photo from an album "Czosnów Days 6th September 2009" depicts the exhibition stand of Kampinos National Park during a commune picnic. Another two photos come from already mentioned albums and show the director of Kampinos National Park greeting the Italian delegation on the Palmiry cemetery, and the director with other representatives of the Park laying wreaths at the tomb of M. Rataj. The context of these photos show that representatives of Kampinos National Park participate in the social life of the commune, however on the basis of quite skimpy photo material presented in the "Gallery", it is difficult to draw any conclusions about the character and the scope of cooperation between the commune and Kampinos National Park representatives.

The final tourist image hallmark identified in the initial part of this research is Modlin and Kazun Defendants Monument. In an album entitled "Patriotic Religious Celebrations 14th November 2013" among 16 photos, there is one depicting the monument. The very title of the album shows the context in which the picture is located, exactly the same as the leading context for the first two image hallmarks, that is the context of patriotic/religious celebrations.

Summing up this part of the research that deals with the visual contents located in the "Gallery" section of the commune website, it is worth stressing that the contents have a significant image-building potential for Czosnów commune, first of all, due to a great number of photos (nearly 2000) presenting the life of the commune and its image. Tourists forming their opinions about the commune, thanks to the "Gallery's" contents have access to photo documentation of different types of events held in the commune: from patriotic/religious celebrations, through mass 
events of sport/recreation nature, picnics and street/family festivities, to the activities of local artistic groups or cultural and educational institutions and associations. Therefore, this section of the website can be deemed highly useful as far as the first stage of tourists' experiences is concerned, that is forming the image of the region before an intended visit. What concerns the second stage, that is searching for information, this section of the website undoubtedly facilitates the process by giving titles to each album and providing at least one-sentence description of the documented event. However, what hinders the process is the lack of chronology among the albums, and the lack of captions for many photographs (especially those referring to the image hallmarks). The latter problem significantly lowers the value of this section as a source of information.

The next section in Czosnów commune official website is the section entitled "Tourism". Unfortunately, contrary to common expectations of prospective tourists, its contents are quite disappointing. It contains a subsection on agrotourism with contact data, description and some photos of two farms rendering tourist services and a subsection referring to Kampinos National Park. The subsection gives a very brief description of the Park only, without any information about tourist routes, and without even giving a link to the official website of the Park. The "Tourism" section does not present a wider scope of information about accommodation (although there are other tourist farms and a hotel in the commune), there is no information about catering services or tourist attractions in the commune. Both quantitative and qualitative content analyses of this section reveal that it cannot be useful for tourists: neither in the process of forming their image of the place, nor in searching for information about it. In fact, it must be said that this section is the weakest part of the website's contents, as far as tourism image of the commune is concerned. It must be remembered that prospective tourists will intuitionally first of all consult this section when looking for information before the intended journey. Unfortunately, they will get only a very limited information package, and the image of the commune that can be formed on this basis might be an image of a commune that is not interested in developing tourism, or even restricting tourism in their area. This is of course a possible image strategy, but a one that might be used by those destination which fear excessive development of tourism, detrimental to their wellbeing. Is that the case of Czosnów commune?

The answer to this question (at least partial) can be found in the section entitled "Remaining information", which includes a subsection "Commune investments with funding". One of the posts in this subsection briefly describes a project of "Welcoming signs - small project, great effect, i.e. improving the tourist image of Czosnów commune" within the framework of 413 Activity "Implementing local development strategies". According to the post the aim of the project was "promoting attractive places and attracting tourists to Czosnów commune (...). Within the framework of the same activity an info board was prepared with the commune map showing interesting places. Both the board and the welcoming signs play an important role, apart from informational function, they are an element of tourism promotion" (Czosnów Commune a, n.d.). Content analysis of this post shows that the commune does not fear excessive development of tourism. On the contrary, it is interested in attracting tourists and undertakes activities promoting its tourist image. Therefore, the poor contents of the "Tourism" section are most astonishing, because the tourist image of the commune they project is at least partially false.

The remaining two sections of the website entitled "Foreign cooperation" and "Important telephone numbers" contain information that is useful first of for the inhabitants of the commune not for the tourists. 


\section{Conclusion}

The research focused on the way in which the contents presented on the official website of Czosnów commune were correlated with the tourist image hallmarks of the commune. In the initial part of the research four hallmarks were identified: (1) cemetery and museum in Palmiry, (2) cemetery and monument in Wiersze, (3) Modlin and Kazun Defendants Monument, (4) Kampinos National Park. The identified image hallmarks are strong enough to function as a basis for the process of forming a tourist image of the commune and as a stepping stone for the local tourist product development.

In the core part of the research the commune's website contents were analyzed in terms of the image hallmarks' presence and contexts of their appearance in the posts. The quantitative content analysis showed that among the 12 sections of the website, 3 sections included contents referring to the image hallmarks. It was the first section entitled "Commune" with one very short post referring to Kampinos National Park, one equally short post referring to cemetery and celebrations in Palmiry, and one post mentioning the name of the village Wiersze, but not referring to the image hallmark. The ninth section entitled "Tourism" contained one post referring to Kampinos National Park. Most of the contents referring to the image hallmarks were found in the eighth section "Gallery". Among the nearly 2000 photographs in this section, there were 82 photos showing or referring to any of the four image hallmarks. The qualitative content analysis of this material showed that visual contents referring to the four image hallmarks appeared in four contexts. The most strongly represented was the context of patriotic/religious celebrations held in Palmiry, in Wiersze and in Kazun Nowy. The second context was that of combining mass events of sport/recreational nature with elements of commemorating historical events in Palmiry and in Wiersze. The third context was the functioning of these two image hallmarks (cemeteries in Palmiry and Wiersze) as important special places, visited by foreign guests in the commune. Finally, the forth, and the most weakly represented was the context of artistic photos of both cemeteries and Kampinos National Park.

When evaluating the contents' usefulness for potential tourists forming their image of the commune or searching for information before the intended visit, it is worth stressing that the website gives access to rich photo material, particularly referring to the first and the second image hallmark. Tourists can see what the cemetery in Palmiry and cemetery and monument in Wiersze look like, they can learn what kind of events have already been held there, and they can form their opinion about the role of these places in the social life of the commune. Unfortunately, in case of the other two hallmarks, the photo material is not as rich, moreover the contents of posts in other sections of the website do not give access to a wider scope of information useful for tourists. The ninth section "Tourism" is astonishingly poor in this respect. Its contents have very low informational value, and do not have any potential for building the image of the commune being interested in the development of tourism in its area. Such potential is certainly bigger in the eighth section "Gallery", first of all, due to a large number of photographs documenting the life of the commune and its image.

\section{References}

All-Polish Computer Base of Military Cemeteries (n.d.). Cmentarz wojenny żołnierzy Armii Krajowej grupy Kampinos (Military Cemetery of Home Army soldiers of the Kampinos Regiment). Available at: http://groby.radaopwim.gov.pl/grob/9136 (accessed on: 25.10.2014).

Beerli, A. \& Martin, J.D. (2004). Tourists' Characteristics and the Perceived Image of Tourist Destinations: A Quantitative Analysis A case study of Lanzarote, Spain. Tourism Management, 25: 623-636. 
Biegger, T. \& Laesser, C. (2004). Information Sources for Travel Decisions: Toward a Source Process Model. Journal of Travel Research, 42 (4): 357-371.

Björk, P. \& Kauppinen-Räisänen, H. (2015). Contemporary insights to the dynamic pre-trip information sourcing behavior. Tourism and Hospitality Research, 15: 39-53.

Bonn, M., Joseph, S. \& Dai, M. (2005). International versus Domestic Visitors: An Examination of Destination Image Perceptions. Journal of Travel Research, 43 (3): 294-301.

Czosnów commune a. (n.d.). Europejski Fundusz Rolny na rzecz Rozwoju Obszarów Wiejskich: Europa inwestująca w obszary wiejskie (European Agricultural fund for Rural Development: Europe investing in rural areas). Available at: http://czosnow.pl/viewpage. php?page_id=27 (accessed on: 27.10.2014).

Czosnów commune b. (n.d.). Flaga (Flag). Available at: www.czosnow.pl/news.php?readmore=36 (accessed on 25.10.2014).

Czosnów commune c. (n.d.). Galeria (Gallery). Available at: www.czosnow.pl/photogallery.php (accessed on 25.10.2014).

Czosnów commune d. (n.d.). Historia (History). Available at: http://czosnow.pl/news.php (accessed on 25.10.2014).

Czosnów commune e. (n.d.). Historia (History). Available at: www.czosnow.pl/viewpage.php?page_id=2 (accessed on 25.10.2014).

Czosnów commune f. (n.d.). Położenie (Location). Available at: www.czosnow.pl/viewpage.php?page_id=3 (accessed on 25.10.2014).

Czosnów commune g. (n.d.). Partnerstwo w widłach trzech rzek (Parnership in the forking of three rivers). Available at: www.3rzeki.pl/ upload/File/informacje_dla_inwestora/Gmina_Czosnow.pdf (accessed on 25.10.2014).

Czosnów commune h. (n.d.). Polak-Węgier dwa bratanki (Pole and Hungarian cousins be). Available at: www.czosnow.pl/photogallery. php?album=97 (accessed on 25.10.2014).

Echtner, C. \& Ritchie, J.B. (2003). The Meaning And Measurement of Destination Image. Journal of Tourism Studies, 14 (1): $37-48$.

Engel, J., Blackwell, R. \& Miniard, P. (1995). Consumer Behavior. 8th Edition. Fort Worth: Dryden.

Hawkins, D., Motherbaugh, D. \& Mookerjee, A. (2010). Consumer Behavior: Building Marketing Strategy. 11th Edition. New Delhi: Tata McGraw-Hill.

Gartner, W.C. (1993). Image Formation Process. Journal of Travel \& Tourism Marketing, 2 (3): 191-215.

Gołębiewski, T., (n.d). Niepodległa Rzeczpospolita Kampinoska (The Independent Republic of Kampinos). Available at: http://www. ibprs.pl/ak_obroza_kampinos/41.html (accessed on 25.10.2014).

Govers, R., \& Go, F. (2003). Deconstructing destination image in the information age. Information Technology and Tourism, 6 (1): $13-29$.

Govers, R. (2005). Virtual Tourism destination Image: Glocal Identities Constructed, Perceived and Experienced. Rotterdam School of Management Erasmus University. Available at: http://repub.eur.nl/pub/6981/EPS2005069MKT_9058921077_GOVERS.PDF (accessed on 20.03.2015).

Gursoy, D., \& Umbreit, W.T. (2004). Tourist information search behavior: cross cultural comparison of European Union member states. Hospitality Management, 23: 55-70.

Hwang, Y., Gretzel, U., Xiang, Z. \& Fesemaier, D.R. (2006). Information Search for Travel Decisions. In: D.R. Fesenmaier, K.W. Wöber, H. Werthner. Destination Recommendation Systems: Behavioural Foundations and Applications. Wallingford: CAB International (pp. 3-16).

Inexhibit, Memorial Museum in Palmiry by WXC. Available at: www.inexhibit.com/case-studies/memorial-museum-palmiry-wxca (accessed on 20.03.2015).

Kim, H. \& Fesenmaier, D.R. (2008). Persuasive Design of Destination Web Sites: An Analysis of First Impression. Journal of Travel Research, 47 (1): 3-13.

Krippendorf , K. (2005). Content Analysis. An Introduction to its Methodology. Thousand Oaks: Sage Publications.

Lin, C-H., Duarte, B., Kerstetter, D.L. \& Hou, J-S. (2007). Examining the Role of Cognitive and Affective Image in Predicting Choice Across Natural, Developed and Theme-Park Destinations. Journal of Travel Research, 46: 183-194.

Lopes, S. (2011). Destination Image: Origins, Developments and Implications. PASSOS. Revista de Tourismo y Patrimonio Cultural, 9 (2): 305-315.

Matos, N., Mendes, J., \& Valle, P. (2012). Revisiting the destination image construct through a conceptual model. Dos Algarves. A multidisciplinary e-journal. 21: 101-117. Available at: www.dosalgarves.com/revistas/N21/5rev21.pdf (accessed on 20.03.2015).

Morrison, A.M., Taylor, J.S., \& Douglas, A. (2004).Website Evaluation in Hospitality and Tourism: The Art Is Not Yet Stated. Journal of Travel \& Tourism Marketing, 17 (2/3): 233-251. 
Pan, B. \& Fesenmaier, D.R. (2006). Information Search and Navigation in the Internet. In: D.R. Fesenmaier, K.W. Wöber, H. Werthner. Destination Recommendation Systems: Behavioural Foundations and Applications. Wallingford: CAB International (pp. 30-44).

Patton, M.Q. (2002). Qualitative Research and Evaluation Methods. Thousand Oaks: Sage Publications.

San Martin, H. \& Rodriguez, I.A. (2008). Exploring the cognitive-affective nature of destination image and the role of psychological factors in its formation. Tourism Management, 29 (2): 263-277.

Tasci, A. (2007). Assessment of factors influencing destination image using a multiple regression model. Tourism Review, 62 (2): 23-30. Weber, R.P. (1990). Basic Content Analysis. Newbury Park: Sage Publications.

Żagiel, S. (2002). Tajemnice kazuńskiego pomnika (The mysteries of Kazuń Monument). Tygodnik Ciechanowski (Ciechanów Weekly). Available at: www.tc.ciechanow.pl/aktualnosc-1163-tajemnice_kazunskiego_pomnika.html (accessed on: 25.10.2014).

Citle this article aS: Ćwiklińska, J. (2015). Rural commune's website contents in the process of forming its tourist image. The case of Czosnów, Poland. Szczecin University Scientific Journal, No. 883. Service Management, 16 (2): 5-17. 
